\section{Orthopedic injuries in 156 equids in the Federal District, Midwestern Brazil}

\author{
Injúrias ortopédicas em 156 equídeos no Distrito Federal, \\ Centro-Oeste do Brasil
}

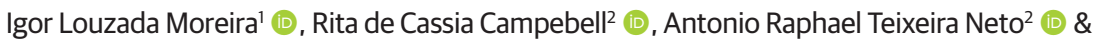 \\ Antonio Carlos Lopes Câmara² (D) \\ 'Veterinary, Post-graduate student. Programa de Pós-graduação em Saúde Animal, Faculdade de Agronomia e Medicina \\ Veterinária - FAV, Universidade de Brasília - UNB, Brasília, DF, Brasil \\ Veterinarys, Dr. Hospital Escola de Grandes Animais, Faculdade de Agronomia e Medicina Veterinária - FAV, Universidade de \\ Brasília - UNB, Brasília, DF, Brasil
}

\begin{abstract}
The present study aimed to establish the prevalence of orthopedic injuries and main clinical-epidemiological findings in equids referred to the Large Animal Veterinary Teaching Hospital of the Universidade de Brasilia (HVET-UNB), during a 2-year period (March 2016 to February 2018). All equids records during the 2-year period were reviewed to select the orthopedic injury cases. Animal records were divided into two groups: traction animals and those participating in other equestrian activities. Definitive diagnosis, reached by means of physical evaluation and ancillary diagnostic (radiography and ultrasonography) methods, showed that 34\% (156 cases) of the referred 438 equids, presented some sort of orthopedic disorders. Of these cases, 151 (96.8\%) were horses, four (2.6\%) mules, and one (0.6\%) donkey. Ninety (58\%) were traction horses and 66 (42\%) participated in other equestrian activities, while 45.5\% (71/156) were females and $54.5 \%$ (85/156), males. Forelimbs were the most affected (51.9\% - 81/156), followed by hind limbs (41.1\% 64/156) and vertebral column disorders (7\% - 11/156). Furthermore, 75\% (117/156) presented some degree of lameness while $25 \%$ (39/156) had no pain or gait alterations. The three major orthopedic injuries were bone disorders (40.4\% - 63/156), tendinopathies (25.6\% - 40/156) and arthropathies (13.5\% - 21/156), while the digital (9\% - 14/156), muscle (6.4\% - 10/156) and ligament (5.1\% - 8/156) injuries were observed less frequently. Total mortality rate reached $32.7 \%$ (51/156), and fractures represented the major orthopedic disease leading to euthanasia (80.4\% - 41/51). The high number of traction equids attended (90 animals - 58\%) indicates the still frequent use of these animals in large urban centers. The high mortality rate in this category (50\% - 45/90), representing 90.1\% (45/51) of all deaths, reveals the need for developing public policies prohibiting horses from circulating in urban areas while also improving their welfare in the rural area. We reiterate the importance of retrospective studies for identifying risk factors, proposing management changes and creating policies to avoid animal suffering and financial losses.
\end{abstract}

Keywords: arthropathies, equids, fractures, tendinopathy, retrospective study.

\section{Resumo}

O presente estudo objetivou estabelecer a prevalência de lesões ortopédicas e os principais achados clínicoepidemiológicos em equídeos encaminhados ao Hospital Veterinário de Grandes Animais da Universidade de Brasilia (HVET-UNB), durante o período de dois anos (março de 2016 a fevereiro de 2018). Todos os registros de equídeos durante este período foram revisados; e casos de lesões ortopédicas selecionados. Os animais foram divididos em dois grupos: animais de tração e outras atividades. O diagnóstico definitivo foi obtido por avaliação física e métodos diagnósticos auxiliares (radiografia e ultrassonografia). No período de dois anos, 438 equídeos foram encaminhados para o HVET-UNB, onde as injúrias ortopédicas foram responsáveis por 34\% (156 casos) dos atendimentos. Destes casos, 151 (96,8\%) eram equinos, quatro (2,6\%) muares e um (0,6\%) asinino. Noventa (58\%) foram equídeos de tração e 66 (42\%) utilizados em outras atividades equestres. Em relação ao gênero, 45,5\% (71/156) eram fêmeas, e, 54,5\% (85/156), machos. Os membros torácicos foram os mais acometidos (51,9\% - 81/156), seguidos dos membros pélvicos (41,1\% 64/156) e coluna vertebral (7\% - 11/156). Além disso, 75\% (117/156) apresentaram algum grau de claudicação, enquanto 25\% (39/156) não apresentaram alterações de dor ou na marcha. As três principais lesões ortopédicas foram as osteopatias (40,4\% - 63/156), tendinopatias (25,6\% - 40/156) e artropatias (13,5\% 21/156). Contando com menor frequência houve lesões digitais (9\% - 14/156), musculares (6,4\% - 10/156) e ligamentares (5,1\% - 8/156). A mortalidade total atingiu 32,7\% (51/156), e as fraturas representaram a
How to cite: Moreira, I. L., Campebell, R. C., TeixeiraNeto, A. R., Câmara, A. C. L. (2019). Orthopedic injuries in 156 equids from Distrito Federal, Midwestern Brazil. Brazilian Journal of Veterinary Medicine, 41, e095619. doi: 10.29374/2527-2179. bjvm095619

Financial support: Dr. Moreira thanks the National Council of Scientific and Technological Development (CNPq) for the granted scholarship.

Conflict of interests: No conflict of interests declared concerning the publication of this article.

Received: May 22, 2018.

Accepted: April 10, 2019

The study was performed in the Large Animal Veterinary Teaching Hospital of the University of Brasília, Brasília, DF, Brasil.

\section{*Correspondence}

Antonio Carlos Lopes Câmara

Hospital Escola de Grandes Animais,

Universidade de Brasília - UNB

Área Especial SRB, Galpão 4, Granja do Torto CEP 70636-200 - Brasília (DF), Brasil

E-mail: aclcamara@yahoo.com.br
Copyright Moreira et al. This is an Open Access article distributed under the terms of the Creative Commons Attribution Non-Commercial License which permits unrestricted non-commercial use, distribution, and reproduction in any medium provided the original work is properly cited. 
principal doença ortopédica causando eutanásia (80,4\% - 41/51). O grande número de equídeos de tração atendidos ( $n=90$ - 58\%) mostra o uso ainda frequente desses animais em grandes centros urbanos. A alta taxa de mortalidade nessa categoria (50\% - 45/90), representando 90,1\% (45/51) de todos os óbitos, revela a necessidade de desenvolvimento de políticas públicas que proíbam a circulação desses equídeos em áreas urbanas e também melhorem sua condição de bem-estar naárea rural. Reiteramos a importância de estudos retrospectivos na identificação de fatores de risco, proposição de mudanças na gestão e políticas para evitar o sofrimento dos animais e perdas financeiras.

Palavras-chave: artropatias, equídeos, estudo retrospectivo, fraturas, tendinopatias.

\section{Introduction}

The equid population in Brazil is the third largest in the world, estimated at 5.3 million animals, of which approximately 17,000 animals are in the Federal District (Ministério da Agricultura, Pecuária e Abastecimento, 2016). Orthopedic injuries are important in the clinical routine of the species (Pierezan et al., 2009; Tipton et al., 2013; Marcolongo-Pereira et al., 2014). The type of activity, anatomical conformation, environment, nutrition and management influence the prevalence of musculoskeletal injuries (Evans \& Walsh, 1997; Murray et al., 2006; Menarin et al., 2012). Furthermore, the training program and type of sports activity may overload specific anatomic structures, predisposing the animals to such lesions and lameness (Murray et al., 2006).

In this sense, retrospective studies, especially those covering different systems, allow determining the frequency of the main diseases, their epidemiological aspects and economic losses to the equestrian activity (Pierezan et al., 2009; Marcolongo-Pereira et al., 2014). Recently, a six-year period retrospective study on traction equids attended at the Large Animal Veterinary Teaching Hospital of the Universidade de Brasília (HVET-UNB), reported a 29\% prevalence of primary locomotor disorders (Rehbein, 2016). This percentage becomes even more significant considering the total number of equids referred to the institution. Therefore, the present study aimed to establish the prevalence of orthopedic injuries and main clinical-epidemiological findings in 156 equids referred to HVET-UNB, in the two-year period (March 2016 to February 2018).

\section{Materials and methods}

The records of all equids referred to HVET-UNB during the two-year period (March 2016 to February 2018) were reviewed to select the cases of orthopedic injuries. The equids were divided into two groups: traction animals and those participating in other equestrian activities (horseback riding, rodeo, cowboy mounting, endurance riding, barrel racing/drum, etc.). The conclusive diagnosis was reached by physical evaluation and ancillary diagnostic (radiography and ultrasonography) methods.

The data were grouped and classified according to the species, gender, anatomical region (fore or hind limbs), presence of lameness and physical nature (tendinous, bone, articular, muscular, ligament and digital). The data were, then, tabulated in Microsoft Excel $2010^{\circledR}$ spreadsheet and analyzed regarding the frequency distribution of the variables (Pierezan et al., 2009). The total mortality rate was estimated and, also, the mortality related to each condition.

\section{Results}

In the two-year period, of the total 438 equids referred to HVET-UNB, 34\% (156 cases) represented orthopedic injuries, of which 151 (96.8\%) were horses, four (2.6\%) mules, and one (0.6\%) donkey. Ninety (58\%) were traction animals while 66 (42\%) participated in other activities, whereas $45.5 \%$ (71/156) were females and 54.5\% (85/156), males. Forelimbs were the most affected (51.9\% - 81/156), followed by hind limbs (41.1\% - 64/156) and vertebral column disorders (7\% - 11/156). Furthermore, $75 \%$ (117/156) of the equids had some degree of lameness while 25\% (39/156) showed no signs of pain while moving or gait alterations.

The most prevalent orthopedic disorders are shown in Table 1 . Of the total medical records evaluated, bone disorders reached 40.4\% (63/156), followed by tendinopathies (25.6\% - 40/156), arthropathies (13.5\% - 21/156), podopathies (9\% - 14/156), myopathies (6.4\% - 10/156), and desmopathies (5.1\% - 8/151). The total number and percentage of deaths per disease are presented in Table 2. A total of 51 animals (32.7\% - 51/156) died or were euthanized, of which 45 (88.2\%) were 
Table 1. Prevalence of the main orthopedic diseases in 156 equids attended at the Large Animal Veterinary Teaching Hospital of Universidade de Brasília, from March 2016 to February 2018.

\begin{tabular}{|c|c|c|c|}
\hline \multirow{2}{*}{ Disease } & \multicolumn{2}{|c|}{ Number of equids } & \multirow{2}{*}{ Total (\%) } \\
\hline & Traction & Other activities & \\
\hline Bone disorders & 47 & 16 & $63(100 \%)$ \\
\hline \multicolumn{4}{|l|}{ Fractures } \\
\hline Radius and ulna & 11 & 0 & $11(17 \%)$ \\
\hline Tibia and fibula & 4 & 1 & $5(8 \%)$ \\
\hline Third metacarpal & 3 & 0 & $3(5 \%)$ \\
\hline Third metatarsal & 4 & 2 & $6(10 \%)$ \\
\hline Sesamoid & 1 & 0 & $1(2 \%)$ \\
\hline First phalanx & 1 & 1 & $2(3 \%)$ \\
\hline Vertebral & 6 & 2 & $8(13 \%)$ \\
\hline Fourth metacarpal & 0 & 1 & $1(2 \%)$ \\
\hline Carpal & 2 & 0 & $2(3 \%)$ \\
\hline Spacula & 2 & 1 & $3(5 \%)$ \\
\hline Humerus & 2 & 0 & $2(3 \%)$ \\
\hline Femur & 2 & 0 & $2(3 \%)$ \\
\hline Pelvis & 4 & 0 & $4(6 \%)$ \\
\hline Jaw & 0 & 1 & $1(2 \%)$ \\
\hline Naviculitis & 0 & 2 & $2(3 \%)$ \\
\hline Enthesophytosis & 2 & 0 & $2(3 \%)$ \\
\hline Periostitis & 0 & 4 & $4(6 \%)$ \\
\hline Carpus valgus & 3 & 1 & $4(6 \%)$ \\
\hline Tendinopathies & 20 & 20 & $40(100 \%)$ \\
\hline \multicolumn{4}{|l|}{ Tendinous lacerations } \\
\hline CDET & 6 & 5 & $11(27,5 \%)$ \\
\hline CDET and LnDET & 0 & 2 & $2(5 \%)$ \\
\hline LnDET & 2 & 0 & $2(5 \%)$ \\
\hline SDFT and DDFT & 2 & 2 & $4(10 \%)$ \\
\hline DDFT & 1 & 0 & $1(2.5 \%)$ \\
\hline SDFT & 0 & 1 & $1(2.5 \%)$ \\
\hline \multicolumn{4}{|l|}{ Tendinitis } \\
\hline DDFT & 0 & 3 & $3(7.5 \%)$ \\
\hline SDFT and DDFT & 0 & 1 & $1(2.5 \%)$ \\
\hline SDFT & 0 & 3 & $3(7.5 \%)$ \\
\hline Infraspinal & 1 & 0 & $1(2.5 \%)$ \\
\hline Flexural deformity & 6 & 2 & $8(20 \%)$ \\
\hline Tenosynovitis & 0 & 1 & $1(2.5 \%)$ \\
\hline Higroma & 1 & 0 & $1(2.5 \%)$ \\
\hline Bicipital bursitis & 1 & 0 & $1(2.5 \%)$ \\
\hline
\end{tabular}

CDET: common digital extensor tendon; LDET: lateral digital extensor tendon; LnDET: long digital extensor tendon; DDFT: deep digital flexor tendon; SDFT: superficial digital flexor tendon; SL: suspensory ligament; SLEB: SL extensor branches. 
Table 1. Continued..

\begin{tabular}{|c|c|c|c|}
\hline \multirow{2}{*}{ Disease } & \multicolumn{2}{|c|}{ Number of equids } & \multirow{2}{*}{ Total (\%) } \\
\hline & Traction & Other activities & \\
\hline Arthropathies & 11 & 10 & $21(100 \%)$ \\
\hline Osteoarthrosis/osteoarthritis & 5 & 6 & $11(52 \%)$ \\
\hline Synovitis & 2 & 1 & $3(14 \%)$ \\
\hline Osteochondritis dissecans & 0 & 2 & $2(10 \%)$ \\
\hline Septic polyarthritis & 0 & 1 & $1(5 \%)$ \\
\hline Dislocation & 4 & 0 & $4(19 \%)$ \\
\hline Podopathies & 4 & 10 & $14(100 \%)$ \\
\hline Laminitis & 1 & 7 & $8(57 \%)$ \\
\hline Podal osteitis & 1 & 1 & $2(14 \%)$ \\
\hline Exudative dermovilitis & 2 & 0 & $2(14 \%)$ \\
\hline Hoof wall fracture & 0 & 2 & $2(14 \%)$ \\
\hline Myopathies & 2 & 8 & $10(100 \%)$ \\
\hline Myositis & 1 & 3 & $4(40 \%)$ \\
\hline Rhabdomyolisis & 0 & 2 & $2(20 \%)$ \\
\hline Fibrotic myopathy & 0 & 1 & $1(10 \%)$ \\
\hline Lacerations & 1 & 2 & $3(30 \%)$ \\
\hline Desmopathies & 6 & 2 & $8(100 \%)$ \\
\hline \multicolumn{4}{|l|}{ Desmitis } \\
\hline Tarsal collateral ligaments & 0 & 1 & $1(12.5 \%)$ \\
\hline Medial patellar ligament & 2 & 0 & $2(25 \%)$ \\
\hline Straight sesamoid ligament & 1 & 0 & $1(12.5 \%)$ \\
\hline SLEB partial rupture & 1 & 0 & $1(12.5 \%)$ \\
\hline SL rupture & 1 & 0 & $1(12.5 \%)$ \\
\hline SL mineralization & 1 & 0 & $1(12.5 \%)$ \\
\hline Annular ligament mineralization & 0 & 1 & $1(12.5 \%)$ \\
\hline TOTAL & 90 & 66 & 156 \\
\hline
\end{tabular}

CDET: common digital extensor tendon; LDET: lateral digital extensor tendon; LnDET: long digital extensor tendon; DDFT: deep digital flexor tendon; SDFT: superficial digital flexor tendon; SL: suspensory ligament; SLEB: SL extensor branches.

Table 2. Total number and percentage of deaths/euthanasia per orthopedic disease in 51 equids attended at the Large Animal Veterinary Teaching Hospital of Universidade de Brasília, from March 2016 to February 2018.

\begin{tabular}{lccc}
\hline \multirow{2}{*}{ Disease } & \multicolumn{2}{c}{ Number of dead/euthanised equids } & \multirow{2}{*}{ Total (\%) } \\
\cline { 2 - 3 } & Traction & Other activities & \\
\hline Fractures & 37 & 4 & $41(80.4 \%)$ \\
Flexural deformities & 4 & 0 & $4(7.8 \%)$ \\
Dislocation & 4 & 0 & $4(7.8 \%)$ \\
Laminitis & 0 & 1 & $1(2 \%)$ \\
Rhabdomyolisis & 0 & 1 & $1(2 \%)$ \\
TOTAL & $45(90.1 \%)$ & $6(9.9 \%)$ & $51(100 \%)$ \\
\hline
\end{tabular}


traction equids and six practiced other activities (11.8\%). The mortality rate per category reached 50\% (45/90) and 9\% (6/66) for traction equids and other activities, respectively. Fractures were the main cause of death/euthanasia (41 cases - $80.4 \%$ ), followed by acquired flexural deformities (4 cases - 7.8\%), dislocations (4 cases - 7.8\%), laminitis and rhabdomyolysis (1 case each - $2 \%$ ).

\section{Discussion and conclusions}

The results showed that orthopedic injuries were more frequent in males, with a 9\% difference in the prevalence between males and females. This finding is similar to that described in a study with traction equids in the Federal District, in which 59\% were males and $41 \%$ females (Rehbein, 2016). Likewise, in the municipality of Botucatu, SP, a study with 116 horses reported a percentage of $43 \%$ females and 57\% males (Sousa et al., 2017). However, a study with traction equids in Arapiraca, AL, reported a higher percentage of mares (86.32\%), which according to the authors, they were chosen due to more docile temperament for work, besides being not necessary to stop the traction cart load to urinate, and also their use in reproduction (Mariz et al., 2014).

Forelimbs were the most affected (51.9\% - 81/156), corroborating previous studies (Maranhão et al., 2006; Sousa et al., 2017). This result is explained by the fact that the forelimbs are responsible for supporting up to $65 \%$ of body weight, lifting the animal from the ground, absorbing impacts and executing the maneuvers to change direction (Denoix, 1994), besides other specific activities may overuse these limbs (Hernandez et al., 2001; Sousa et al., 2017). Lameness was observed in 75\% (117/156) of equids suggesting, in most cases, acute or subacute lesions; whereas equids with chronic diseases of podotrochlear apparatus may present important radiographic changes and no degree of claudication (Maranhão et al., 2006). An epidemiological study conducted with racehorses reported that lameness problems were the main cause of interruption of training (67.6\%), followed by respiratory problems (Rossdale et al., 1985; Hernandez \& Hawkins, 2001).

The most prevalent orthopedic injuries were bone disorders (40.4\% - 63/156), with fractures (81\% - 51/63) being the most frequently observed. Recently, in a 24-year retrospective study, the percentage of fractures reached 61.6\% (37/60) (Marcolongo-Pereira et al., 2014), while in another study in the same area covered by the HVET-UNB, the percentage of fractures in traction equids reached 39\% (52/135) (Rehbein, 2016). Muscle-skeletal injuries are the leading cause for missing training days for Thoroughbred horses (Dyson et al., 2008), with fractures accounting for up to $60 \%$ of the fatalities (Verheyen \& Wood, 2004; Legorreta, 2013). In the present study, fractures caused significant economic losses since most equids under these conditions were euthanized, mainly due to the high surgical cost, postoperative complications and unfavorable prognosis for survival and sport (Hernandez et al., 2001; Beisser et al., 2011; Legorreta, 2013).

Among tendinopathies (25.6\% - 40/156), tendinous lacerations represented $52.5 \%$ (21/40) of the cases. A retrospective study in Maringá-PR indicated that activities related to wound management, such as tendon sutures, were one of the most performed procedures, reaching $28.5 \%$ of the cases (Meira et al., 2014). Digital extensor tendon lacerations are associated with large avulsion wounds on the dorsal aspect of the metacarpal or metatarsal bones in horses. These facts evidenced the high incidence of tendinous lacerations in equines caused most commonly by cuts with fence wires, trampling, and kicks on piercing/cutting objects (Belknap et al., 1993). In most cases, lacerations involving digital flexor tendons are associated with unfavorable prognosis, unlike those in the extensor tendon (Foland et al., 1991; Jansson, 1995). Therefore, in the present study, the majority of the animals affected by lacerations had a favorable prognosis, since $71.4 \%(15 / 21)$ presented lacerations of the extensor tendons and only $28.6 \%$ (6/21) of the flexors.

Of the arthropathies, present in $13.5 \%$ (21/156) of the cases, osteoarthrosis/ osteoarthritis were the most diagnosed conditions, with 52\% (11/21). This fact becomes relevant since several studies have found that the main cause of wear and consequent termination of sporting career of young horses is joint disease (Rossdale et al., 1985; Todhunter et al., 1996). The occurrence of this disease in equine athletes is routine and indicated by the prevalence of $11 \%$ obtained for Crioulo horses, followed by $10 \%$ in saddle horses and Quarter horses (Veiga, 2006). The results of this study may be explained by the fact that the animals with such arthropathy, attended at HVET-UNB, were old with low zootechnical value, rendering the treatment unfeasible due to the high cost and unfavorable prognosis since the disease is characterized by progressive deterioration of articular cartilage and bone deformations (Schlueter \& Orth, 2004). 
Additionally, diffuse aseptic pododermatitis (laminitis) was diagnosed in $57.2 \%$ (8/14) of the cases of the podopathies (9\% [14/156]). Laminitis is the most serious and main disease affecting the horses' hooves (Pollitt, 2004), and reported with a considerable incidence in this study, considering the range of foot diseases described in equids and the disease critical prognosis (Pollitt, 2004). The other ungual pathologies, such as podal osteitis and exudative dermovilitis, were observed with lower frequency. However, a study with traction donkeys in São Luiz-MA diagnosed podal osteitis and exudative dermovilitis with 100\% and 42.5\% frequencies, respectively (Chaves et al., 2011).

Among myopathies (6.4\% [10/156]), lacerations and myositis were the most diagnosed, followed by rhabdomyolysis and fibrotic myopathy. Pierezan et al. (2009) evaluated necropsy findings over a 40-year period and reported a prevalence of $21 \%$ for myopathies. Muscular necroses of varied nature, mainly toxic, were the most diagnosed diseases. Muscular diseases in equines have a poorly standardized classification but the improving ability to recognize the clinical syndromes and the use of morphological, biochemical and molecular techniques in diagnosis show a tendency towards standardization in the next few years (Amorim et al., 2011).

With a low prevalence in this study, the predominant ligament disease $(5.1 \%$ - 8/156) was medial patellar desmitis with 25\% (2/8). Likewise, a study on traction equids performed in Belo Horizonte, MG, reported a similar low frequency of 4.3\% (Maranhão et al., 2006). On the other hand, a study with 199 athlete horses practicing several sports that had pain associated with the distal extremity of forelimbs reported a diagnosis of collateral ligament desmitis of the distal interphalangeal (CDDIP) joint in 60 (31\%) of the cases (Dyson et al., 2005). In another study, 16 of the 62 cases (38.75\%) diagnosed with CDDIP involved horses that practiced jumping, complete riding competition, and steeplechase (Dyson et al., 2008). Perhaps the low prevalence of such diseases in some regions is related to the limited ability to reach a conclusive diagnosis since the most accessible technique is ultrasonography, which presents considerable technical limitations of execution (Denoix, 1994). Another relevant factor is that in the area covered by the HVET-UNB, desmitis cases are commonly attended at the training sites.

From the total of 156 equines, 90 (58\%) were traction animals (used for waste collection, recycling, transport services and wandering animals). In large urban centers, the use of traction equids is still a common practice so that the animals are submitted to high-intensity exercises inadequate to their physical condition. Also, factors such as hard flooring, body profile, physical conditioning, nutrition, health, inadequate horseshoeing, hooves quality, age at the beginning of activities, length of working day, lack of veterinary assistance, and disputing spaces with motor vehicles may be predisposing to locomotor system injuries (Oliveira et al., 2007; Rehbein, 2016). Another relevant aspect is the high mortality rate in this category, reaching 50\% (45/90), and accounting for 90.1\% (45/51) of all deaths (Table2). These data reveal the need for the development of public policies prohibiting equines from circulating in urban areas and improving their welfare in the rural area. Considering all categories, the total mortality rate reached 32.7\% (51/156) confirming fractures as highly prevalent, responsible for great economic losses and the main orthopedic disease leading to euthanasia in these species (Verheyen \& Wood, 2004; Legorreta, 2013; Marcolongo-Pereira et al., 2014; Rehbein, 2016).

The present data review reiterates the direct relationship between the type of physical activity and the orthopedic injuries in horses (Sousa et al., 2017) showing that the prevalence of these injuries varies significantly with the activities performed by the equids in the region, the raising profile, the breeds involved and the local culture (Evans \& Walsh, 1997; Murray et al., 2006; Menarin et al., 2012; Tipton et al., 2013). The importance of retrospective studies is highlighted since it helps to identify the risk factors, propose changes in the management and use of equines to avoid financial losses and promote animal welfare.

\section{References}

Amorim, R. M., Rino, A. S., Dal-Pai-Silva, M., Borges, A. S., Oliveira Filho, J. P., Freitas, N. P. P., Maia, L., \& Rezende, L. A. L. (2011). Aspectos morfológicos de biópsias musculares em equinos com miopatia sob forma de surto. Pesquisa Veterinária Brasileira, 31(7), 579-585. http://dx.doi.org/10.1590/50100-736X2011000700006.

Beisser, A. L., McClure, S., Wang, C., Soring, K., Garrison, R., \& Peckham, B. (2011). Evaluation of catastrophic musculoskeletal injuries in Thoroughbreds and Quarter Horses at three Midwestern racetracks. Journal of the American Veterinary Medical Association, 239(9), 1236-1241. http://dx.doi.org/10.2460/javma.239.9.1236. PMid:21999798. 
Belknap, J. K., Baxter, G. M., \& Nickels, F. A. (1993). Extensor tendon lacerations in horses: 50 cases (1982-1988) Journal of the American Veterinary Medical Association, 203(3), 428-431. PMid:8226222.

Chaves, N. P., Bezerra, D. C., Guerra, P. C., Pereira, H. M., Santos, H. P., \& Vulcano, L. C. (2011). Lesões podais em asininos (Equus asinus) utilizados em veículos de tração animal na cidade de São Luiz, Maranhão. Ciência Animal Brasileira, 12(2), 365-370. http://dx.doi.org/10.5216/cab.v12i2.8953.

Denoix, J. M. (1994). Functional anatomy of tendons and ligaments in the distal limbs. The Veterinary Clinics of North America. Equine Practice,10(2), 273-322. http://dx.doi.org/10.1016/S0749-0739(17)30358-9. PMid:7987720.

Dyson, P. K., Jackson, B. F., Pfeiffer, D. U., \& Price, J. S. (2008). Days lost from training by two- and three-year-old Thoroughbred horses: a survey of seven UK training yards. Equine veterinary journal, 40(7), 650-657. http:// dx.doi.org/10.2746/042516408X363242. PMid:19165934.

Dyson, S. J., Murray, R., \& Schramme, M. (2005). Lameness associated with foot pain: results of magnetic resonance imaging in 199 horses (January 2001 - December 2003) and response to treatment. Equine Veterinary Journal, 37(2), 113-121. http://dx.doi.org/10.2746/0425164054223804. PMid:15779622.

Evans, D. L., \& Walsh, J. S. (1997). Effect of increasing the banking of a racetrack on the occurrence of injury and lameness in Standardbred horses. Australian Veterinary Journal, 75(10), 751-752. http://dx.doi. org/10.1111/j.1751-0813.1997.tb12261.x. PMid:9406636.

Foland, J. W., Trotter, G. W., Stashak, T. S., Mcllwraith, C. W., Turner, A. S., \& Aanes, W. A. (1991). Traumatic injuries involving tendons of the distal limbs in horses: a retrospective study of 55 cases. Equine Veterinary Journal, 23(6), 422-425. http://dx.doi.org/10.1111/j.2042-3306.1991.tb03754.x. PMid:1778158.

Hernandez, J., \& Hawkins, D. L. (2001). Training failure among yearling horses. American Journal of Veterinary Research, 62(9), 1418-1422. http://dx.doi.org/10.2460/ajvr.2001.62.1418. PMid:11560271.

Hernandez, J., Hawkins, D. L., \& Scollay, M. C. (2001). Race-start characteristics and risk of catastrophic musculoskeletal injury in Thoroughbred racehorses. Journal of the American Veterinary Medical Association, 218(1), 83-86. http://dx.doi.org/10.2460/javma.2001.218.83. PMid:11149721.

Jansson, N. (1995). Digital extensor tendon lacerations in horses: a retrospective evaluation of 22 cases. Journal of Equine Veterinary Science, 15(12), 537-540. http://dx.doi.org/10.1016/S0737-0806(07)80424-2.

Legorreta, G. G. L. (2013). Ocorrências graves: injúrias catastróficas e não-catastróficas nas corridas no Hipódromo de Cidade Jardim do Jockey Club de São Paulo no período de 1996 a 2006. Veterinária e Zootecnia, 20(3), 9-27.

Maranhão, R. P. A., Palhares, M. S., Melo, U. P., Rezende, H. H. C., Braga, C. E., Silva Filho, J. M., \& Vasconcelos, M. N. F. (2006). Afeç̧ões mais frequentes do aparelho locomotor dos equídeos de tração no município de Belo Horizonte. Arquivo Brasileiro de Medicina Veterinária e Zootecnia, 58(1), 21-27. http://dx.doi.org/10.1590/ S0102-09352006000100004.

Marcolongo-Pereira, C., Estima-Silva, P., Soares, M. P., Sallis, E. S. V., Grecco, F. B., Raffi, M. B., Fernandes, C. G., \& Schild, A. L. (2014). Doenças de equinos na região Sul do Rio Grande do Sul. Pesquisa Veterinária Brasileira, 34(3), 205-210. http://dx.doi.org/10.1590/S0100-736X2014000300002.

Mariz, T. M. A., Escodro, P. B., Dittrich, J. R., Souza Neto, M., Lima, C. B., \& Ribeiro, J. S. (2014). Padrão biométrico, medidas de atrelagem e índice de carga de equídeos de tração urbana do município de Arapiraca, Alagoas. Archives of Veterinary Science, 19(2), 1-8.

Meira, I. R., Lorga, A. D., Catussi, B. L. C., Bortolato, J. S. D., Ferreira, A. G. G., Gaddini, L. V., Rosado, R. S., Borniotti, D. F., Tomio, T. E., Zavileski, R. B., Tramontin, R. S., \& Ribeiro, M. G. (2014). Levantamento casuístico de equinos atendidos no Hospital Veterinário da Universidade Estadual de Maringá no período de março de 2013 a setembro de 2014. Revista Ciências Veterinária e Saúde Pública, 1(supl.1), 67.

Menarin, B. C., Machado, V. M. V., Alvarez, L. E. C., Carneiro, R., Busch, L., \& Vulcano, L. C. (2012). Radiographic abnormalities in barrel racing horses with lameness referable to the metacarpophalangeal joint. Journal of Equine Veterinary Science, 32(4), 216-221. http://dx.doi.org/10.1016/j.jevs.2011.09.064.

Ministério da Agricultura, Pecuária e Abastecimento. (2016). Revisão do estudo do complexo do agronegócio do cavalo. Brasília: MAPA. 56 p. Retrieved in 2018, March 10, from http://www.agricultura.gov.br/ assuntos/camaras-setoriais-tematicas/documentos/camaras-setoriais/equideocultura/anos-anteriores/ revisao-do-estudo-do-complexo-do-agronegocio-do-cavalo

Murray, R. C., Dyson, S. J., Tranquille, C., \& Adams, V. (2006). Association of type of sport and performance level with anatomical site of orthopaedic injury diagnosis. Equine Veterinary Journal, 36(36, Suppl.), 411-416. http:// dx.doi.org/10.1111/j.2042-3306.2006.tb05578.x. PMid:17402457.

Oliveira, L., Marques, R. L., Nunes, C. H., \& Cunha, A. M. (2007). Carroceiros e equídeos de tração: um problema socioambiental. Caminhos de Geografia, 8(24), 204-216.

Pierezan, F., Rissi, D. R., Rech, R. R., Fighera, R. A., Brum, J. S., \& Barros, C. S. L. (2009). Achados de necropsia relacionados com a morte de 335 equinos: 1968-2007. Pesquisa Veterinária Brasileira, 29(3), 275-280. http:/l dx.doi.org/10.1590/S0100-736X2009000300015.

Pollitt, C. C. (2004). Equine laminitis. Clinical Techniques in Equine Practice, 3(1), 34-44. http://dx.doi.org/10.1053/j. ctep.2004.07.003.

Rehbein, L. S. (2016). Atendimento hospitalar aos equídeos de tração do Distrito Federal: Convênio Universidade de Brasília e Secretaria de Agricultura (Monografia). Faculdade de Agronomia e Medicina Veterinária, Universidade de Brasília, Brasília. 
Rossdale, P. D., Hopes, R., Digby, N. J., \& Offord, K. (1985). Epidemiological study of wastage among racehorses 1982 and 1983. The Veterinary Record, 116(3), 66-69. http://dx.doi.org/10.1136/vr.116.3.66. PMid:3976145.

Schlueter, A. E., \& Orth, M. W. (2004). Equine osteoarthritis: a brief review of the disease and its causes. Equine and Comparative Exercise Physiology, 1(4), 221-231. http://dx.doi.org/10.1079/ECP200428.

Sousa, N. R., Luna, S. P. L., Pizzigatti, D., Martins, M. T. A., Possebon, F. S., \& Aguiar, A. C. S. (2017). Relation between type and local of orthopedic injuries with physical activity in horses. Ciência Rural, 47(2), e20151218. http:// dx.doi.org/10.1590/0103-8478cr20151218.

Tipton, T. E., Ray, C. S., \& Hand, D. R. (2013). Superficial digital flexor tendinitis in cutting horses: 19 cases (20072011). Journal of the American Veterinary Medical Association, 243(8), 1162-1165. http://dx.doi.org/10.2460/ javma.243.8.1162. PMid:24094264.

Todhunter, P. G., Kincaid, S. A., Todhunter, R. J., Kammermann, J. R., Johnstone, B., Baird, A. N., Hanson, R. R., Wright, J. M., Lin, H. C., \& Purohit, R. C. (1996). Immunohistochemical analysis of an equine model of synovitisinduced arthritis. American Journal of Veterinary Research, 57(7), 1080-1093. PMid:8807026.

Veiga, A. C. R. (2006). Estudo retrospectivo de casuística, abrangendo metodologia diagnóstica da osteoartite em equinos (Dissertação). Programa de Pós-Graduação em Clínica Veterinária, Universidade de São Paulo, São Paulo.

Verheyen, K. L. P., \& Wood, J. L. N. (2004). Descriptive epidemiology of fractures occurring in British Thoroughbred racehorses in training. Equine Veterinary Journal, 36(2), 167-173. http://dx.doi.org/10.2746/0425164044868684. PMid:15038441. 